\title{
Intraoperative analgesic effects of intratesticular lidocaine in a dog undergoing elective orchiectomy: case report
}

\author{
Efeito analgésico intraoperatória da lidocaína intratesticular em \\ um cão submetido a orquiectomia eletiva: relato de caso
}

\author{
Efecto analgésico intraoperatorio de la lidocaína intratesticular en un \\ perro sometido a orquiectomía electiva: reporte de caso
}

\author{
Albert Ávila Rodríguez ${ }^{1 *}$; Edwin Buriticá-Gaviria ${ }^{2 *}$; Diego Echeverry-Bonilla ${ }^{3}$ \\ $1 \mathrm{Mvz}$ \\ $2 \mathrm{Msc}$; \\ 3 PhD \\ * Grupo de investigación en Medicina y Cirugía de Pequeños Animales. Facultad de Medicina Veterinaria y Zootecnia. \\ Universidad del Tolima. Barrió Santa Helena, Ibagué (Colombia). \\ Email: decheverry@ut.edu.co
}

Recibido: 28 de octubre de $2013 \quad$ Aceptado:26 de noviembre de 2016

\begin{abstract}
A 1-year-old male Cocker Spaniel, weighing $10.5 \mathrm{~kg}$, was referred for elective orchiectomy. An intratesticular injection of lidocaine was performed as a part of multimodal anesthetic protocol that also included: acepromazine, meloxicam, tramadol and ketamine. During the intraoperative period the cardiorespiratory parameters (heart rate, respiratory rate, and mean arterial blood pressure), the intraoperative anesthetic (ketamine) and analgesic (fentanyl) consumption, and the presence of autonomous nociceptive responses were evaluated. Increases of baseline cardiorespiratory parameters above $10 \%$ or the presence of autonomous nociceptive responses would be considered as indicative of insufficient analgesic coverage, for which $1 \mu \mathrm{g} / \mathrm{kg}$ IV of fentanyl would be employed. The evaluated cardiorespiratory variables were stable, and no autonomous nociceptive responses were observed. For this reason no additional ketamine boluses nor rescue analgesics were administered. It is suggested that intratesticular lidocaine, as a part of the multimodal analgesic protocol employed, contributed to improve the analgesic coverage during orchiectomy in this dog.
\end{abstract}

Key words: analgesia, canine, castration, local anesthetic, locoregional anesthesia pain management (Source: MeSH, NCBI)

\section{Resumo}

Um cão da raça Cocker Spaniel de um ano de idade e 10,5kg de peso foi encaminhado para orquiectomia eletiva. Foi realizada a administração de Lidocaína intratesticular como parte de um protocolo de anestesia multimodal que também incluía Acepromazina, Meloxicam, Tramadol e Ketamina. Durante o período intraoperatório foram avaliados os parâmetros cardiorrespiratórios (frequência cardíaca, frequência respiratória e pressão arterial média), o consumo intraoperatório de anestésicos (ketamina) e analgésicos (fentanil), e a presença de respostas nociceptivas autónomas. Incrementos nos valores basais dos parâmetros cardiorrespiratórios superiores a $10 \%$ ou a presença de respostas nociceptivas autónomas foram 
consideradas como indicativo de cobertura analgésica insuficiente, para o qual seria usado $1 \mu \mathrm{gg} / \mathrm{kg}$ IV. As variáveis cardiorrespiratórias avaliadas se mantiveram estáveis e não se observaram respostas nociceptivas autónomas. Por essa razão não se administrou quantidades adicionais de ketamina nem analgesia de resgate. Sugere-se que a lidocaína intratesticular, como parte do protocolo de anestesia multimodal empregado, contribuiu para melhorar a cobertura analgésica durante a orquiectomia nesse cão.

Palavras chaves: analgesia, canino, castração, anestésico local, anestesia loco-regional, manejo da dor.

\section{Resumen}

Un canino de raza Cocker Spaniel de 1 año de edad y $10.5 \mathrm{~kg}$ de peso fue referido para orquiectomía electiva. Se realizó la administración de lidocaína intratesticular como parte de un protocolo de anestesia multimodal que también incluyó acepromacina, meloxicam, tramadol y ketamina. Durante el periodo intraoperatorio fueron evaluados los parámetros cardiorespiratorios (frecuencia cardiaca, frecuencia respiratoria, y presión arterial media), el consumo intraoperatorio de anestésicos (ketamina) y analgésicos (fentanilo), y la presencia de respuestas nociceptivas autónomas. Incremetos en los valores basales de los parámetros cardiorespiratorios superiores al 10\% o la presencia de respuestas nociceptivas autónomas fueron considerados como indicativo de cobertura analgésica insuficiente, para lo cual se emplearía $1 \mu \mathrm{g} / \mathrm{kg}$ IV. Las variables cardiorrespiratorias evaluadas se mantuvieron estables y no se observaron respuestas nociceptivas autónomas. Por esta razón no se administraron bolos adicionales de ketamina ni analgesia de rescate. Se sugiere que la lidocaína intratesticular, como parte de un protocolo de anestesia multimodal empleado, contribuyó a mejorar la cobertura analgesica durante la orquiectomía en este perro.

Palabras clave: analgesia, canino, castración, anestésico local, anestesia locoregional, manejo del dolor.

\section{Introduction}

Orchiectomy in dogs has been related with pain of variable severity, which may vary according to the degree of induced surgical trauma. General anesthesia and preemptive/multimodal analgesia techniques are recommended. There are many options available for perioperative management, some of them included the combined employ of various types of drugs such as: opioids, acepromazine, bendodiazepines, propofol, ketamine, alphaz adrenoceptoragonist, local anesthetics and NSAID's (Tranquili et al., 2007, Gaynor and Muir et al., 2015). Despite the availability of pharmacological options, in many cases the analgesic management during castrations is inadequate even in developed countries (Capner et al., 1999). Due to the economic and technical restrictions (limited availability of some analgesic drugs) in which mass sterilization campaigns are carried out in Colombia, our reality could be even more daunting.

Recently it has been described that intratesticular lidocaine administration is considered an economical (VAASG, 2013) and effective (Mcmillan et al., 2012, Huuskonen et al., 2013, Stevens et al., 2013) method to improve the analgesic coverage during orchiectomy in dogs. These studies were carried out using multimodal analgesia protocol that also included opioids and inhaled anesthesia. The purpose of this case report is to describe the analgesic effect of intratesticular lidocaine, in a dog undergoing elective orchiectomy under a multimodal analgesic protocol and dissociative analgesia. This with the aim of evaluate a pharmacological protocol closer to these employed in our medium.

\section{Case report}

\section{Anamnesis}

An 1-year-old male Cocker Spaniel, weighing $10.5 \mathrm{~kg}$, was referred for elective orchiectomy. The animal was considered healthy based on the results of physical examination and paraclinical tests (complete blood cell count and routine biochemical analyses) (Tables $1,2)$, and was classified as ASA I anesthetic risk patient. The dog was fasted for approximately $8 \mathrm{~h}$ before anesthesia, and water was withdrawn $2 \mathrm{~h}$ before induction. The owners were informed about the surgical and anesthetic procedure to be performed.

Table 1. Results of the blood test achieved to the dog evaluated in this case report

\begin{tabular}{|l|c|c|c|}
\hline \multicolumn{1}{|c|}{ Blood cell } & Result & $\begin{array}{c}\text { Measure } \\
\text { unit }\end{array}$ & Parameter \\
\hline Leukocytes & 9,30 & $103 / \mathrm{dL}$ & $6,0-17,0$ \\
\hline lymphocytes & 2,10 & $103 / \mathrm{dL}$ & $0,8-5,10$ \\
\hline Monocytes & 040 & $103 / \mathrm{dL}$ & $0,0-1,80$ \\
\hline Neutrophils & 6,80 & $103 / \mathrm{dL}$ & $4,0-12,6$ \\
\hline Eosinophils & 0,41 & $103 / \mathrm{dL}$ & $0,1-1,25$ \\
\hline RBC & 7,77 & $106 / \mathrm{dL}$ & $5,50-8,50$ \\
\hline Hemoglobin & 140,0 & $\mathrm{~g} / \mathrm{L}$ & $110-190$ \\
\hline Hematocrit & 45,0 & $\%$ & $39-56$ \\
\hline Platelets & 233,0 & $103 / \mathrm{dL}$ & $180-430$ \\
\hline
\end{tabular}


Table 2. Results of the biochemical evaluation achieved to the dog evaluated in tis case reported patient

\begin{tabular}{|l|c|c|c|}
\hline \multicolumn{1}{|c|}{ Analyte } & Result & $\begin{array}{c}\text { Measure } \\
\text { unit }\end{array}$ & Parameter \\
\hline Creatinine & 1,0 & $\mathrm{mg} / \mathrm{dl}$ & $0,5-1,3$ \\
\hline NUS & 9,5 & $\mathrm{mg} / \mathrm{dl}$ & $8-33$ \\
\hline ALT/GPT & 10 & $\mathrm{mg} / \mathrm{dl}$ & $6-70$ \\
\hline Albumin & 3,0 & $\mathrm{mg} / \mathrm{dl}$ & $2-5$ \\
\hline
\end{tabular}

\section{Anesthetic protocol}

The sedation was performed with $0.2 \mathrm{mg} / \mathrm{kg} \mathrm{IM}$ of acepromazine maleate (Tranquilan ${ }^{\circledR} 1 \%$ ), after 15 minutes the left cephalic vein was cannulated with an intravenous catheter $22 \mathrm{G}$ to infuse $10 \mathrm{ml} / \mathrm{kg} / \mathrm{h}$ of $0.9 \%$ saline. Premedication consisted in the administration of $0.3 \mathrm{mg} / \mathrm{kg}$ IV of $0.5 \%$ meloxicam (Meloxic $₫ 0.5 \%$ ), $3 \mathrm{mg} / \mathrm{kg}$ IV of tramadol (Tramadol ${ }^{\circ} 5 \%$ ). The scrotal skin was shaved and prepared aseptically. Thirty minutes after acepromazine injection, the anesthesia was induced with $5 \mathrm{mg} / \mathrm{kg}$ IV of ketamine (Ketanir ${ }^{\circledR} 5 \%$ ) and maintained with boluses of ketamine $(2,5 \mathrm{mg} / \mathrm{kg})$. Five minutes later, a $1 \mathrm{cc}$ syringe attached to a 1 " $22 \mathrm{G}$ needle was employed to administer $2 \mathrm{mg} / \mathrm{kg}$ of lidocaine (lidocaine ${ }^{\circledR} 2 \%$ ) via intratesticular. The total volume of lidocaine was divided into three parts that were injected as follows: One third was divided into equal portions and injected under the skin of each scrotal sack incision lines. Then, in each testis was injected a third of the total volume of lidocaine $(0.66 \mathrm{mg} / \mathrm{kg})$. For intratesticular injection of lidocaine the needle was introduced into the caudal pole of each testis and then directed toward cranial in direction to the spermatic cord. Once the needle tip was in the cranial pole, negative aspiration test was performed, and then lidocaine injection was performed while the syringe was slowly withdrawn (Figure 1).

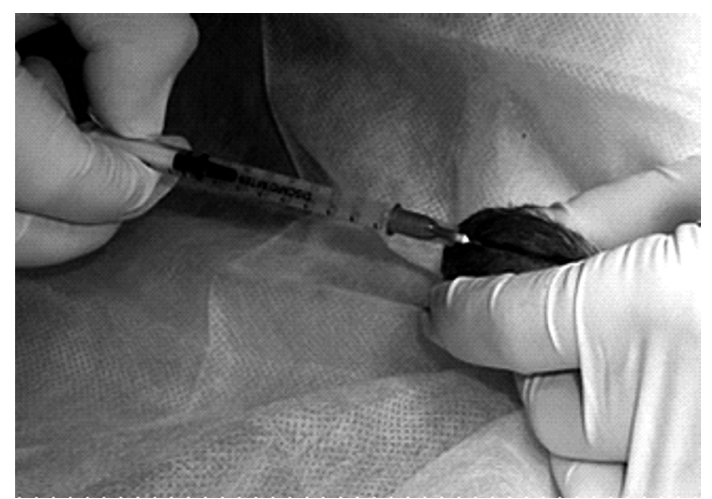

Figure 1. Detail of the position of the needle and syringe for the intratesticular injection of lidocaine in the dog evaluated in the present case report.

\section{Intraoperative anesthetic monitoring}

Heart (HR) and respiratory (RR) rates were assessed using an iM12E multiparameter monitor (Biocare $\left.{ }^{\circledR}\right)$. The mean arterial blood pressure (MBP) was assessed using oscilloscope method placing the bracelet on the right hind limb. These physiological variables were registered during the entire surgical procedure, and specifically in the following operative times: T0 (before induction with ketamine), T1 (5 minutes after induction), T2 (left scrotal skin infiltration), T3 (right scrotal skin infiltration), T4 (left testis infiltration), T5 (right testis infiltration), T6 (left scrotal incision), T7 (left testicle shrinkage), T8 (ligation of the left spermatic cord), T9 (clamping and cutting of the left spermatic cord), T10 (right scrotal incision), T11 (right testicle shrinkage), T12 (ligation of the spermatic cord), T13 (clamping and cutting of the spermatic cord right). Increases of baseline physiological parameters above $10 \%$ (considering the obtained in $\mathrm{T} 1$ as baseline parameters), or the presence of algic movements or vocalization would be considered as indicative of insufficient analgesic coverage, for which $1 \mu \mathrm{g} / \mathrm{kg}$ IV of fentanyl (Fentanex® 0.5\%) would be used as rescue analgesia. The bilateral scrotal orchiectomy was performed by a veterinarian with experienced in this procedure and using the technique described by Fossum (2004). No postoperative pain assessment was performed.

\section{Results of intraoperative monitoring}

The total operative time was 21 minutes, throughout the procedure the evaluated physiological variables were stable (Table 3): heart rate between 125 and 136 beats per minute, mean arterial pressure between 107 and $118 \mathrm{~mm} \mathrm{Hg}$. The respiratory rate was maintained between 19 and 35 breaths per minute, and no algic movements or vocalization were observed. Because of the above described, ketamine maintenance boluses and rescue anesthesia were not used. In the recovery period the patient evidenced vocalizations and disorientation. Tramadol was continued by IM injection every $12 \mathrm{~h}$ for 4 days.

\section{Discussion}

The intratesticular lidocaine infiltration, as a part of a multimodal analgesic protocol employed here, could contribute to provide an adequate intraoperative analgesic coverage during the orchiectomy in this dog. This technique could be especially useful in clinical settings where the availability of opioids drugs and general anesthesia could be limited. 
Table 3. Results of the evaluated cardiorespiratory parameters during of the studied operative times (T1-T13). HR: hearth rate, MAP: mean arterial blood pressure, RR: respiratory rate in a dog undergoing elective orchiectomy.

\begin{tabular}{|c|c|c|c|}
\hline & HR & MAP & RR \\
\hline T1 & 125 & 107 & 19 \\
\hline T2 & 128 & 109 & 18 \\
\hline T3 & 128 & 107 & 18 \\
\hline T4 & 130 & 107 & 19 \\
\hline T5 & 131 & 109 & 19 \\
\hline T6 & 126 & 108 & 18 \\
\hline T7 & 126 & 108 & 20 \\
\hline T8 & 128 & 114 & 25 \\
\hline T9 & 136 & 118 & 35 \\
\hline T10 & 133 & 115 & 28 \\
\hline T11 & 133 & 112 & 25 \\
\hline T12 & 133 & 113 & 27 \\
\hline T13 & 134 & 115 & 30 \\
\hline
\end{tabular}

Surgical times: T1 (5 minutes after induction), T2 (left scrotal skin infiltration), T3 (right scrotal skin infiltration), T4 (left testis infiltration), T5 (right testis infiltration), T6 (left scrotal incision), T7 (left testicle shrinkage), T8 (ligation of the left spermatic cord), T9 (clamping and cutting of the left spermatic cord), T10 (right scrotal incision), T11 (right testicle shrinkage), T12 (ligation of the spermatic cord), T13 (clamping and cutting of the spermatic cord right).

Orchiectomy is a painful surgical procedure commonly performed in the clinical practice, and is indicated in cases of benign prostatic hyperplasia, testicular cancer, perineal hernia, and as sterilization method (Boothe, 1994). Unfortunately, in many countries, including developed countries, orchiectomy is performed without an adequate analgesic coverage. A study performed in the United Kingdom showed that only $30 \%$ of veterinarians administered analgesics during castrations in dogs. The $27 \%$ of them administered NSAIDs, $50 \%$ opioids, and 23\% administered both NSAIDs and opioids (Capner et al., 1999).

Preemptive/multimodal analgesia and inhaled anesthesia is the "gold standard" protocol for providing analgesia during castration in dogs. This involves the application of various drugs normally NSAIDs, opioids and local anesthetics, which act at different levels in the pain pathway (Hellyer et al., 2007, Tranquili et al., 2007, Mcmillan et al., 2012, Huuskonen et al., 2013, Gaynor and Muir et al., 2015). Its use can improve the perioperative analgesic coverage while decreasing the toxicity of the employed drugs (Hellyer et al., 2007,
Tranquili et al., 2007). Among the drugs used in multimodal anesthetic protocols, local anesthetics are the only ones able to effectively block the transmission of acute pain impulse and thus decreasing the chronic pain presentation (Tranquili et al., 2007, Gaynor and Muir et al., 2015). Despite the previously described benefits of the use of lidocaine in multimodal anesthesia protocols (Mcmillan et al., 2012, Huuskonen et al., 2013, Stevens et al., 2013), in Colombia lidocaine would not being applied routinely as an analgesic method during canine orchiectomy.

In Colombia due to economic factors and the limited availability of some analgesics drugs (Baez et al., 2007) during mass sterilization campaigns, the castrations should be made using combinations of drugs such as xylazine, acepromazine, and ketamine (Ruiz et al., 2009) which do not produce sufficient analgesic coverage for this type of surgical procedure. This is contrary to the Colombian Animal Protection Law (Art 84 of 1989), which states that is veterinarians' obligation "to prevent and treat the pain and suffering of animals".

With the aim of reducing the impact of the absence of opioids and general anesthesia during the orchiectomy in this dog, a multimodal anesthetic protocol that included the intratesticular infiltration of lidocaine, plus more accesible drugs such as acepromazine, meloxican, tramadol, and ketamine were employed. Acepromazine is widely used as a sedative in veterinary anesthetic practice; it produces some degree of muscle relaxation but has no analgesic effects. Xylazine alone or in combination with opioid is used in dogs to provide analgesia and sedation during minor surgical procedures (Tranquili et al., 2007, Gaynor and Muir et al., 2015). Ketamine is a noncompetitive antagonist of NMDA receptors routinely used as anesthetic in veterinary medicine. However, at doses below to $10 \mathrm{mg} / \mathrm{kg}$ would not be sufficient to provide visceral analgesia (Tranquili et al., 2007). A study comparing the efficacy and cardiorespiratory effects of the administration of dexmedetomidine and ketamine in combination with various opioids (buprenorphine, hydromorphone, buprenorphine) and carprofen in dogs undergoing elective orchiectomy showed that some patients within each experimental group required a greater supplementation with isoflurane (Barletta et al., 2011). Regarding the tramadol, a study comparing the analgesic effect of tramadol versus morphine during castration in dogs, concluded that tramadol appears less effective than morphine in preventing nociception during the intraoperative period during this surgery (Kongara et al., 2013). 
Assessment of pain in animals still remains a challenge for a number of reasons. In non-sedated dogs spontaneous pain behaviors such as reluctance to move, aggressive, vocalization could be indicative of pain status (Tranquili et al., 2007, Gaynor and Muir et al., 2015). However, in sedated animals much of these pain behaviors could be depressed or neglected by effect of the anesthesia. Noxious stimuli during lighter stages of general anesthesia will generate autonomic responses such as tachycardia, hypertension, and hyperventilation that could be indicative of incomplete analgesic coverage (Tranquili et al., 2007, Gaynor and Muir et al., 2015). Although non-painful stimuli (hypovolemia and hypercapnia, among others.) may produce alterations in these autonomic responses (Tranquili et al., 2007, Gaynor and Muir et al., 2015) many studies considered that increases greater than $10-20 \%$ in relation to baseline values of $H R, R R$ and MBP could be indicative of insufficient analgesic coverage (Wenger, 2004, Caniglia et al., 2012, Huuskonen et al., 2013).

In the patient of the present report, the evaluated cardiorespiratory parameters were stable during the entire surgical procedure, therefore was not necessary to employ rescue analgesia or additional maintenance ketamine boluses. Although it is complex to determine the real contribution of a particular analgesic drug when a multimodal anesthesia protocol is used, as was the case of the employed in this patient. It is considered that the intratesticular injection of lidocaine could contribute in an important way to achieve the analgesic coverage in this dog. Similar results have been described in other study evaluating the isoflurane sparing effect after intratesticular administration of lidocaine in dogs undergoing elective orchiectomy. The dogs of that study received a multimodal anesthetic protocol that also included: acepromazine, morphine, carprofen, plus inhaled anesthesia (Mcmillan et al., 2012). The intratesticular lidocaine group received $1 \mathrm{mg} \mathrm{kg}$ of lidocaine $2 \%$ via intratesticular, and the control group received saline. The results of that study showed that intratesticular administration of lidocaine allowed reducing isoflurane requirements. This reduction was evidenced in the lidocaine group especially during the spermatic cord cutting (which is considered the more painful surgical moment in the orchiectomy), thus indicating that intratesticular lidocaine block autonomic nociceptive stimulus generated in response to the spermatic cord cutting. This also indicated that the sole employ of morphine and carprofen did not allowed achieving an effective analgesic coverage to perform castrations in dogs. In the same study was observed an increase in isoflurane requirements in response to scrotal skin incision. In the patient of the present report scrotal subcutaneous infiltration of lidocaine could contribute to obtain an adequate pain control associated with scrotal skin incision. It is also important to note that in this patient the analgesic coverage achieved was obtained using a lower lidocaine doses $(0.66 \mathrm{mg} / \mathrm{kg})$ as employed by McMillan et al., (2012). This reduction in lidocaine doses can reduce the risk of toxicity associated with its employ. Other study describing the analgesic efficacy of included intratesticular lidocaine during castration in dogs has been publicated (Huuskonen et al., 2013)

\section{Conclusion}

In summary we consider that intratesticular administration of lidocaine under the multimodal anesthetic protocol employed here, was a simple, cheap and effective method for improving the analgesic coverage during elective orchiectomy in this dog. However, controlled clinical studies with larger sample size to validate the results of the present anesthetic protocol are required.

\section{References}

Adin CA. Complications of ovariohysterectomy and orchiectomy in companion animals. Vet Clin Small Anim. 2011;41(5):10231039.

Baez PC, Ruiz I, Restrepo LF, Ruiz JD. Comparación de dos protocolos anestésicos para ovariohisterectomía en perras sanas. Rev Colom Cienc Pecua. ;20(4):425-430.

Barletta M, Austin BR, Ko JC, Payton ME, Weil AB, Inoue T. Evaluation of dexmedetomidine and ketamine in combination with opioids as injectable anesthesia for castration in dogs. J Am Vet Med. ;238(9):1159-1167.

Boothe HW. 1994. Surgery of the testis and scrotum. In: Birchard SJ, Sherding RG (eds.). Small Animal Practice. Saunders, Philadelphia. Pp:882-886.

Caniglia AM, Driessen B, Puerto DA, Bretz B, Boston RC, Larenza MP. Intraoperative antinociception and postoperative analgesia following epidural anesthesia versus femoral and sciatic nerve blockade in dogs undergoing stifle joint surgery. JAVMA. ;241(12):1605-1612.

Capner CA, Lascelles BD, Waterman-Pearson AE. Current British veterinary attitudes to perioperative analgesia for dogs. Vet Rec. ;145(4):95-99.

Fossum TW. 2004. Cirugía en Pequeños Animales. Segunda edición. Buenos Aires (Arg), Intermedica, Pp. 1492.

Gaynor JS, Muir WW. 2015. Handbook of veterinary pain management. Third edition. Missouri (USA), Elsevier. Pp. 620.

Hellyer P, Rodan I, Brunt J, Downing R, Hagedorn JE, Robertson SA. AAHA/AAFP pain management guidelines for dogs \& cats. J Am Anim Hosp Assoc. ;43 (5):235-48. 
Huuskonen V, Hughes JM, Estaca BE, West E. Intratesticular lidocaine reduces the response to surgical castration in dogs. Vet Anaesth Analg. ;40(1):74-82.

Jackman J, Rowan A. Free-roaming Dogs in Developing Countries: The Benefits of Capture, Neuter, and Return Programs, The state of the animals IV 2007; [04/10/13]URL:http://www.fao. org/fileadmin/user_upload/animalwelfare/1_CNVR\%20Jackman\%20and\%20Rowan\%20(2).pdf.

Jana K, Samanta PK. Sterilization of male stray dogs with a single intratesticular injection of calcium chloride a dose-dependent study. Contraception. ;75(5):390-400.

Kongora K, Chambers JP, Johnson CB, Dukkipati VS. Effects of tramadol or morphine in dogs undergoing castration on intraoperative electroencephalogram responses and post-operative pain. N Z Vet J. ;61(6):349-353.

McMillan MW, Seymour CJ, Brearley JC. Effect of intratesticularlidocaine on isoflurane requirements in dogs undergoing routine castration. J Small AnimPract. ;53(7):393-397.

OIE. Código Sanitario para los Animales Terrestres. Directrices sobre el control de las poblaciones de perros vagabundos. Anexo XVII 2010, Capitulo 7.7, pp: 313-332 [15/06/13] URL:http:// www.oie.int/es/normas-internacionales/codigo-terrestre/.
Raekallio M, Heinonen KM, Kuussaari J, Vainio O. Pain alleviation in animals: attitudes and practices of Finnish.Veterinarians. Vet J. 2003;165(2):131-135.

Ruiz JD, Zapata J, Londoño CM, Sánchez RA, Peña JA. Evaluación del efecto de cuatro protocolos anestésicos y cirugías de ovariohisterectomia lateral sobre el hemograma en hembras caninas. Rev Ces Med Vet Zootec. 2009;4(1):25-38.

Stevens BJ, Posner LP, Jones CA, Lascelles BD. Comparison of the effect of intratesticular lidocaine/bupivacaine vs. saline placebo on pain scores and incision site reactions in dogs undergoing routine castration. Vet J. 2013;196(3):499-503.

Tranquili WJ, Thurmon JC, Grimm KA. 2007. Lumb\& Jones Veterinary Anesthesia and Analgesia, Blackwell Publishing. 4th edit. lowa, USA, p.1096.

VAASG, Veterinary Anesthesia \& Analgesia Support Group.Intratesticular blocks 2013.[9/10/13]http://www.vasg.org/ intratesticular_blocks.htm.

Wenger S. Brachial plexus block using electrolocation for pancarpal arthrodesis in a dog. Vet Anaesth Anal. ;31(4):272-275. 